\title{
Evaluation of Parkia pendula lectin mRNA differentially expressed in seedlings
}

\author{
Rêgo, MJBM. ${ }^{a *}$, Santos, PB. ${ }^{a}$, Carvalho-Junior, LB. ${ }^{a, b}$, Stirling, J. ${ }^{c}$ and Beltrão, EIC ${ }^{a, b}$ \\ ${ }^{a}$ Laboratory of Immunopathology Keizo Asami, Department of Pathology, Federal University of Pernambuco - UFPE, \\ Avenida Professor Moraes Rêgo, s/n, CEP 50670-901, Recife, PE, Brazil \\ ${ }^{b}$ Department of Biochemistry, Federal University of Pernambuco - UFPE, \\ Avenida Professor Moraes Rêgo, s/n, CEP 50670-901, Recife, PE, Brazil \\ 'Laboratory of Molecular Genetics, Division of Life Sciences, King's College London, \\ Strand, London WC2R 2LS, United Kingdom \\ *e-mail: moacyr.rego@gmail.com
}

Received August 27, 2012 - Accepted February 1, 2013 - Distributed May 31, 2014

(With 1 figure)

\begin{abstract}
Parkia pendula (Willd.) Walp. (Fabaceae) is a neotropical species of the genus Parkia more abundantly distributed in Central to South America. From the seeds of P. pendula a glucose/mannose specific lectin (PpeL) was isolated that has been characterised and used as a biotechnological tool but until now this is the first manuscript to analyse $P$. pendula mRNA expression in seedlings. For this porpoise a Differential display reverse transcription polimerase chain reaction (DDRT-PCR) was used to evaluate the expression of $P$. pendula lectin mRNAs in non-rooted seedlings. No bands were observed in the agarose gel, indicating the absence of mRNA of PpeL seedlings. our findings confirm that lectins mRNAs are differently regulated among species even if they are grouped in the same class.
\end{abstract}

Keywords: PpeL, DDRT-PCR, seedlings.

\section{Avaliação de mRNA da lectina de Parkia pendula diferencialmente expressa em plântulas}

\section{Resumo}

Parkia pendula (Willd.) Walp. (Fabaceae) é a espécie neotropical do gênero Parkia mais abundantemente distribuída na América Central a do Sul. Das sementes de P. pendula foi isolada uma lectina glicose/manose específica (Ppel) que foi caracterizada e usada como ferramenta biotecnológica, porém até o momento esse é o primeiro artigo a analisar a expressão do mRNA nas plântulas de $P$. pendula. Para esse propósito uma reação de PCR diferencial de transcriptase reversa (DDRT-PCR) foi utilizada para avaliar a expressão do mRNA da lectina de $P$. pendula em plântulas não enraizadas. Nenhuma banda foi observada no gel de agarose, indicando a ausência de mRNA das plântulas de PpeL. Nossos achados confirmam que os mRNAs de lectinas são regulados de forma diferentes entre as espécies, mesmo que sejam agrupadas na mesma classe

Palavras-chave: PpeL, DDRT-PCR, plântula.

\section{Introduction}

The identification and isolation of eukaryotic genes differentially expressed in cell/tissues as a result of genetic, environmental and/or induced variation have been pursued by researchers in many areas of biology, such as developmental biology and plant physiology (Munin et al., 2004). Liang and Pardee (1992) introduced a powerful technique called differential display reverse transcription polymerase chain reaction (DDRT-PCR). The idea was to use a set of arbitrary primers for PCR amplification of complementary DNA (cDNA) generated by RT from mRNA.

Understanding the decay of messenger RNAs (mRNAs) in cells is essential for understanding mRNA turnover and overall regulation of gene expression (Salvador et al., 2011). Most plant mRNAs have half-lives of several hours and are believed to be stable unless they are actively destabilised (Sullivan and Green, 1993). During seed development a number of mRNAs accumulate and then decline in developmentally regulated patterns, including those for important seed proteins like storage proteins, enzymes for starch biosynthesis (Johnson et al., 1999). The complex physiological and biochemical changes that 
occur during seedling development and maturation of plant seeds concerning protein differences reflect changes in gene expression and mRNA abundance.

Parkia pendula (Willd.) Walp. (Fabaceae) is the most widely distributed Neotropical Parkia species, occurring in lowland terra-firme forests from Honduras in Central America southwards to the Atlantic Forest of the Brazilian state of Espírito Santo. This tree species is a typical and abundant species of the Atlantic Forest endemism centre of Pernambuco (Piechowski and Gottsberger, 2009). From the seeds of $P$. pendula a glucose/mannose specific lectin was isolated that has been characterised and used as tool in histochemistry (Beltrão et al., 2003).

Lectins are a structurally diverse class of (glyco) proteins which bind mono- and oligosaccharides with high specificity and in a reversible way (Nasi et al., 2009). They are particularly abundant in the seeds of legumes, making up as much as $10 \%$ of the total seed proteins (Etzler, 1986). The seed lectins accumulate in protein storage vacuoles of cotyledons and are degraded during seed germination and maturation of seedlings (Pusztai et al., 1981).

This work aimed to examine the Parkia pendula lectin (PpeL) mRNA abundance during the seedling stage and in the late stage of maturity of the seed using DDRT-PCR. For this purpose the Parkia pendula seeds were surface-sterilised and grown in constant white light at room temperature. Seedlings were collected at 4 day intervals from the first day of germination (day 4, day 8, day 12) using the method of Logemann et al. (1987), modified for our experiment.

\section{Materials and Methods}

Seedlings had their roots and leaves removed before RNA isolation. Seedlings $(500 \mathrm{mg}$ ) were ground to a fine powder in pre-chilled mortar and pestle in liquid nitrogen. Total RNA was isolated using Tri-reagent (Sigma, USA). The final RNA preparations were quantified by spectrophotometric measurements and stored at $-20^{\circ} \mathrm{C}$. Reverse transcription was performed using oligo $\left(\mathrm{dT}_{12}\right)$ primer and RNA isolated from each seedling stage. For each reaction $1 \mathrm{mg}$ of RNA, $5 \mathrm{mM}$ oligo $\left(\mathrm{dT}_{12}\right)$ primer, $20 \mathrm{mM}$ dNTP, $40 \mathrm{mU}$ Rnasin and $300 \mathrm{U}$ AMV reverse transcriptase and water up to $20 \mathrm{~mL}$ final volume were mixed and incubated at room temperature for $15 \mathrm{~min}$. RT reaction was developed at $40^{\circ} \mathrm{C}$ for $60 \mathrm{~min}$ and stopped by incubation at $95^{\circ} \mathrm{C}$ for $5 \mathrm{~min}$. 12 mer deoxyoligothymidine primers with two extra different nucleotides - oligo-dT ${ }_{12} \mathrm{XY}(\mathrm{X}$ and $\mathrm{Y}=\mathrm{A}, \mathrm{C}, \mathrm{G}$ or T) and oligo-dT $_{12}$ were used as 3 ' end primers. An internal amino acid sequence of the PpeL was used to design the 5' PpeL primer: [5'-(TC)TT(AG)AA(ACGT)(CC)(AT)CCA(AG) TA(AG)TC(ACTG)CC-3']. All degenerate codons were included in the PpeL primer. Four sets of primers were used (Table 1) in the PCR reaction.

In the total volume of $20 \mathrm{~mL}$ the PCR mixtures contained $2.5 \mathrm{mM}$ of $\mathrm{dT}_{12} \mathrm{XY}$ primer (each), $0.5 \mathrm{mM}$ of PpeL primer, $2.0 \mathrm{mM}$ of dNTPs, $1 \mathrm{~mL}$ of RT reaction product, $10 \mathrm{mM}$ Tris- $\mathrm{HCl}$ (pH 8.3), $50 \mathrm{mM} \mathrm{KCl,} 2.5 \mathrm{mM}$
Table 1. Sets of primers used in the PCR

\begin{tabular}{cc}
\hline Set & \multicolumn{1}{c}{ Primers } \\
\hline 1 & 5 '-dT \\
2 & ' $-\mathrm{dT}_{12} \mathrm{AA}, \mathrm{dT}_{12} \mathrm{AC}, \mathrm{dT}_{12} \mathrm{AG}, \mathrm{dT}_{12} \mathrm{AT}$ and 3'-PpeL \\
3 & 5 '- $-\mathrm{dT}_{12} \mathrm{CA}, \mathrm{dT}_{12} \mathrm{CC}, \mathrm{dT}_{12} \mathrm{CG}, \mathrm{dT}_{12} \mathrm{CT}$ and 3'-PpeL \\
4 & 5 '- $\mathrm{dT}_{12} \mathrm{GA}, \mathrm{dT}_{12} \mathrm{GC}, \mathrm{dT}_{12} \mathrm{GG}, \mathrm{dT}_{12} \mathrm{GT}$ and 3'-PpeL \\
\hline
\end{tabular}

PpeL - Parkia pendula Lectin.

$\mathrm{MgCl}$ and $1 \mathrm{U}$ Taq polymerase. Amplification was done for 35 cycles with $94{ }^{\circ} \mathrm{C}$ for $90 \mathrm{sec}, 62{ }^{\circ} \mathrm{C}$ for $60 \mathrm{sec}$ and $72{ }^{\circ} \mathrm{C}$ for $120 \mathrm{sec}$ and an additional extension period at $72{ }^{\circ} \mathrm{C}$ for $5 \mathrm{~min}$.

PCR products were run in an $8 \%$ agarose gel in Tris/ Borate/EDTA solution (TBE) at $80 \mathrm{~V}$. Samples and $1 \mathrm{~Kb}$ DNA ladder was diluted in Tris Borate solution (TE) and loading buffer (Sambrook et al., 1989). RNA isolation from seedlings and mature seeds of Parkia pendula yielded a high amount or pure RNA (260/280 ratio $\geq 1$.6). RNA analyses by formaldehyde-agarose gel showed a great number of bands indicating that RNAs were properly isolated and were not contaminated by protein.

\section{Results and Discussion}

No evidence of PpeL mRNA was observed in agarose gel electrophoresis of PCR products (Figure 1). Earlier studies of temporal and spatial distribution of legume seed lectins have demonstrated that they accumulate specifically during seed formation (Van Damme et al., 1995). This spatial and temporal regulation of these genes is the subject of a considerable amount of research. In spite of temporal expression, Van Damme et al. (1997) observed that the bark lectin from the Japanese pagoda tree (Sophora japonica L.) were accumulated at new shoots during the autumn indicating a developmental pattern different from the legumen seed lectins.

Our findings of mRNA absence for PpeL seedlings (with no roots) are in accordance with studies related to the expression of a wheat-germ agglutining (WGA) gene in embryos and young seedlings of Triticum aestivum L. (Raikhel et al., 1988). The study demonstrated that wheat embryo development is characterised by an increase and subsequent decline in the level of WGA-B mRNA, which encodes the isolectin $\mathrm{B}$, to a low level in dry seeds. It was also reported that WGA-B mRNA is expressed in the root caps of seedlings. Firstly, it was believed that the mRNA detected in the root caps of seedlings represented carryover from embryos but experiments unequivocally demonstrated that WGA-B mRNA is synthesised again in the root caps of seedlings.

Experiments with the mannose-binding lectins from Clivia miniata L. demonstrated a high expression level of this lectin in its mature seed endosperm (Van Damme et al., 1994). For their experiments young developing ovaries were the organ of choice for total RNA isolation for cDNA library generation. Northern blotting analysis of total RNA isolated from different tissues of Clivia miniata 


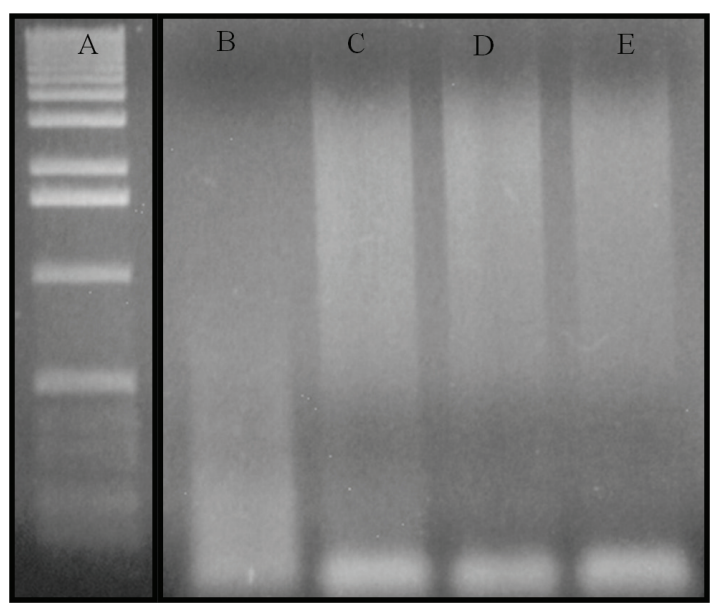

Figure 1. Agarose-gel ( $8 \%$ ) of PCR products using RNA isolated from the 4 day-old seedling of Parkia pendula and different sets of primers. Lane A, $1 \mathrm{~Kb}$ DNA ladder; lane B, primer set 1; lane $\mathrm{C}$, primer set 2; lane $\mathrm{D}$, primer set 3 and lane E, primer set 4 . The absence of bands at the top and the middle of figure indicates that there wasn't Ppel mRNA. The bands at the end of the figure represent primer dimers.

showed that the lectin is expressed with very high lectin mRNA concentration in the ovary and the seed endosperm. The pattern of almost complete absence of some protein mRNA in seedlings is also observed to other proteins different of lectins such as calmodulin from maize. During embryo development, calmodulin mRNAs were most abundant between 10 and 30 days after pollination (dap), decreased 40 dap and were almost undetectable in seedlings (Breton et al., 1995).

On the other hand, Esteban et al. (2002) characterised a clone, CanVLEC, encoding a vegetative lectin from chickpea (Cicer arietinum L. cv. Castellana). The expression of the CanVLEC gene was specific in seedlings, mostly in hooks and elongating epicotyls, and no expression was detected in adult plants. The level of chickpea vegetative lectin transcripts in epicotyls decreased through the epicotyl growth suggesting a relationship to development.

Nakamura et al. (2004) showed that a Japanese chestnut lectin CCA mRNA expression was maintained at a high level during development, was at a relatively low level during dormancy, and showed subsequent high expression during germination. Differing from CAA lectin gene expressed constitutively in various plant tissues including flower, leaf, root and stem. When chickpea lectin mRNA level was checked in developing seeds, it was higher in 10 days after flowering seeds and decreased throughout seed development (Qureshi et al., 2007).

Our findings of mRNA absence for PpeL seedlings confirm that these molecules are differently regulated among species even if they are grouped in the same class. The next step towards the determination of where and when the mRNA of PpeL is expressed is to carry out experiments with different parts of the seed in different periods of germination, development and maturation.
Acknowledgements - We thank CNPq (Conselho Nacional de Desenvolvimento Científico e Tecnológico, Brazil) for financial support, CAPES (Coordenação de Aperfeiçoamento de Pessoal de Nivel Superior, Brazil) and FACEPE (Fundação de Amparo à Ciência e Tecnologia do Estado de Pernambuco, Brazil) for schollarships and financial support.

\section{References}

BELTRÃO, EIC., MEDEIROS, PL., RODRIGUES, OG., FIGUEREDO-SILVA, J., VALENÇA, MM., COELHO, LCBB. and CARVALHO, LB Jr., 2003. Parkia pendula lectin as histochemistry marker for meningothelial tumour. European Journal of Histochemistry: EJH, vol. 47, no. 2, p. 139-142. PMid:12777210

BRETON, C., CHABOUD, A., MATTHYS-ROCHON, E., BATES, EEM., COCK, JM., FROMM, H. and DUMAS, C., 1995. PCR-generated cDNA library of transition-stage maize embryos: cloning and expression of calmodulin genes during early embryogenesis. Plant Molecular Biology, vol. 27, no. 1, p. 105-113. http://dx.doi.org/10.1007/BF00019182. PMid:7865780

ESTEBAN, R., DOPICO, B., MUÑOZ, FJ., ROMO, S. and LABRADOR, E., 2002. A seedling specific vegetative lectin gene is related to development in Cicer arietinum. Physiologia Plantarum, vol. 114, no. 4, p. 619-626. http://dx.doi.org/10.1034/ j.1399-3054.2002.1140416.x. PMid:11975737

ETZLER, ME., 1986. The Lectins: properties, functions and applications in biology and medicine. Orlando: Academic Press.

JOHNSON, RR., CHAVERRA, ME., CRANSTON, HJ., PLEBAN, T. and DYER, WE., 1999. Degradation of oat mRNAs during seed development. Plant Molecular Biology, vol. 39, no. 4, p. 823-833. http://dx.doi.org/10.1023/A:1006179315016. PMid:10350095

LIANG, P. and PARDEE, AB., 1992. Differential display of eukaryotic messenger RNA by means of the polymerase chain reaction. Science, vol. 257, no. 5072, p. 967-971. http://dx.doi. org/10.1126/science.1354393. PMid:1354393

LOGEMANN, J., SCHELL, J. and WILLMITZER, L., 1987. Improved method for the isolation of RNA from plant tissues. Analytical Biochemistry, vol. 163, no. 1, p. 16-20. http://dx.doi. org/10.1016/0003-2697(87)90086-8. PMid:2441623

MUNIN, FS., SCHWANTES, ML., SCHWANTES, AR. and MOREIRA-FILHO, O., 2004. NADP-dependent isocitrate dehydrogenase of Astyanax scabripinnis (Pisces, Characidae) from three altitudes at Grande Stream, Campos do Jordão, SP. Brazilian Journal of Biology, vol. 64, no. 2, p. 273-282. http:// dx.doi.org/10.1590/S1519-69842004000200013.

NAKAMURA, S., IKEGAMI, A., MIZUNO, M., YAGI, F. and NOMURA, K., 2004. The expression profile of lectin differs from that of seed storage proteins in Castanea crenata trees. Bioscience, Biotechnology, and Biochemistry, vol. 68, no. 8, p. 1698-1705. http://dx.doi.org/10.1271/bbb.68.1698. PMid:15322353

NASI, A., PICARIELLO, G. and FERRANTI, P., 2009. Proteomic approaches to study structure, functions and toxicity of legume seeds lectins. Perspectives for the assessment of food quality and safety. Journal of Proteomics, vol. 72, no. 3, p. 527-538. http:// dx.doi.org/10.1016/j.jprot.2009.02.001. PMid:19217948

PIECHOWSKI, D. and GOTTSBERGER, G., 2009. The seedpod gum of Parkia pendula (Fabaceae) as a deadly trap for vertebrates. Biotemas, vol. 22, no. 1, p. 175-177. 
PUSZTAI, A., GRANT, G. and STEWART, JC., 1981. A new type of Phaseolus vulgaris (cv Pinto III) seed lectin: isolation and characterization. Biochimica et Biophysica Acta, vol. 671, no. 2, p. 146-154. http://dx.doi.org/10.1016/0005-2795(81)90128-8.

QURESHI, IA., DASH, PK., SRIVASTAVA, PS. and KOUNDAL, KR., 2007. Isolation and characterization of a lectin gene from seeds of chickpea (Cicer arietinum L.). DNA Sequence: the journal of DNA sequencing and mapping, vol. 18, no. 3, p. 196-202. http://dx.doi.org/10.1080/10425170601060608. PMid:17454004

RAIKHEL, NV., BEDNAREK, SY. and WILKINS, TA., 1988. Cell-type-specific expression of a wheat-germ agglutinin gene in embryos and young seedlings of Triticum aestivum. Planta, vol. 176, no. 3, p. 406-414. http://dx.doi.org/10.1007/BF00395422. PMid:24220870

SALVADOR, ML., SUAY, L. and KLEIN, U., 2011. Messenger RNA degradation is initiated at the $5^{\prime}$ end and follows sequenceand condition-dependent modes in chloroplasts. Nucleic Acids Research, vol. 39, no. 14, p. 6213-6222. http://dx.doi.org/10.1093/ nar/gkr226. PMid:21507888

SAMBROOK, L., FRITSCH, EF. and MANIATIS, T., 1989. A laboratory manual. New York: Cold Spring Harbor Laboratory Press.
SULLIVAN, ML. and GREEN, PJ., 1993. Post-transcriptional regulation of nuclear-encoded genes in higher plants: the roles of mRNA stability and translation. Plant Molecular Biology, vol. 23, no. 6, p. 1091-1104. http://dx.doi.org/10.1007/BF00042344. PMid:8292775

VAN DAMME, EJ., SMEETS, K., VAN LEUVEN, F. and PEUMANS, WJ., 1994. Molecular cloning of mannose-binding lectins from Clivia miniata. Plant Molecular Biology, vol. 24, no. 5, p. 825-830. http://dx.doi.org/10.1007/BF00029865. PMid:8193308

VAN DAMME, EJ., BARRE, A., ROUGÉ, P., VAN LEUVEN, F. and PEUMANS, WJ., 1995. The seed lectins of black locust (Robinia pseudoacacia) are encoded by two genes which differ from the bark lectin genes. Plant Molecular Biology, vol. 29, no. 6, p. 1197-1210. http://dx.doi.org/10.1007/BF00020462. PMid: 8616218

VAN DAMME, EJM., BARRE, A., ROUGÉ, P. and PEUMANS, WJ., 1997. Molecular cloning of the bark and seed lectins from the Japanese pagoda tree (Sophora japonica). Plant Molecular Biology, vol. 33, no. 3, p. 523-536. http://dx.doi. org/10.1023/A:1005781103418. PMid:9049272 